\title{
MEMBANGUN KARAKTER GURU BERBASIS AKSIOLOGI
}

\author{
Oleh: \\ Mutmainah ${ }^{1}$ \\ Email: mutmainah.zainul@yahoo.com
}

\begin{abstract}
Building a teacher who has a characteristic personality if viewed from a philosophical aspect of axiology is to question the nature of the personality of the teacher because the teacher in carrying out his duties in educating children must be in accordance with the purpose of education where the teacher must be able to integrate all the character values into everyday life. In other words, these values are embedded in the teacher's personal, so that the teacher must fulfill the competencies of the educator and education staff in order to meet professional competence as a character educator who is finally able to instill these character values in students.
\end{abstract}

Key words: teacher, character, professional, axiology.

\section{Pendahuluan}

Kesuksesan pendidikan bukan sekedar mendatangkan peserta didik memenuhi kelas di sekolah. Tantangan terberat justru memastikan para peserta didik mendapatkan layanan pendidikan bermutu sehingga mereka mampu mencapai tujuan belajar, menyelesaikan sekolah, dan memiliki kemampuan menghadapi masa depan. Untuk mencapai pendidikan yang berkualaitas, guru memiliki peran penting dan strategis. Institusi penyelenggaraan pendidikan membutuhkan guru-guru ideal, berkualitas, terlatih, dan bermotivasi tinggi dalam menjalani profesi dan tanggung jawabnya.

Tantangan tersebut tidak mudah untuk dihadapi. Guru harus mampu menjaga keseimbangan antara tuntutan untuk berbuat normatif ideal dengan suasana kehidupan masa kini yang ditandai dengan pola kehidupan materialistis, pragmatis, individualistis, kompetitif dan lain

${ }^{1}$ Dosen Prodi Pendidikan Bahasa Arab STAI Syaichona Moh. Cholil Bangkalan 
sebagainya. Maka, mewujudkan guru profesional sangat urgen untuk diterapkan. Sebab salah satu indikator mutu pembelajaran/pendidikan adalah kinerja guru yang profesional.

Bagaimana membangun guru yang memiliki kepribadian berkarakter jika dipandang filsafat dari aspek aksiologi adalah mempermasalahkan hakikat kepribadian berkarakter guru karena guru dalam melaksanakan tugasnya dalam mendidik anak sesui dengan tujuan pendidikan merupakan suatu pendidikan yang menguji dan mengintegrasikan semua nilai tersebut dalam kehidupan manusia. Dengan kata lain nilai-nilai tersebut ditanamkan dalam pribadi guru. Sehingga guru harus memenuhi kompetensi tenaga pendidik dan kependidikan guna menujang kompetensi profesional sebagai pendidik yang berkarakter.

\section{Pembahasan}

\section{Guru Yang Berkarakter}

Secara harfiah karakter berarti cetak biru, sidik jari, jati diri, sifat dasar, watak yang melekat atau chemestry. Lebih dari itu karakter juga berkaitan dengan akhlak, budi pekerti, sopan santun, dan moralitas. Karakter ini merupakan proses dan hasil antropologis manusia yang bersifat holistik, integrated dan komprehensif, yakni merupakan bentuk akumulasi dan perpaduan antara unsur kebebasan dan keterbatasan manusia dengan lingkungan yang mempengaruhinya. Karakter tersebut terlihat pada kemampuan manusia mengekspresikan kebebasan dan pilihannya secara bertanggung jawab baik kepada hati nuraninya maupun kepada masyarakat. Dengan demikian, guru yang berkarakter adalah guru yang memiliki jati diri, sifat, watak dasar serta chemistry yang unik dan jelas serta berbeda dengan orang lain. Guru berkarakter adalah guru yang terbina potensi jasmani dan rohani, intelektual, sosial, dan berbagai kompetensi lainnya secara utuh. Guru yang berkarakter adalah guru yang memiki kebebasan untuk menyatakan pilihannya secara bertanggung jawab, serta mampu berbuat dan bertindak dalam hubungannya dengan masyarakat. ${ }^{2}$

${ }^{2}$ Abuddin Nata. (2012). Kapita Selekta Pendidikan Islam. Jakarta: Raja Grafindo Persada. Hlm 237. 
Dengan demikian guru yang berkarakter adalah guru yang bermoral, akhlak mulia, budi pekerti, sopan santun, etika, agama, dan nilai-nilai kewarganegaraan. Guru demikian itu selanjutnya mengambil inisiatif, kreatifitas, pilihannya secara bertanggung jawab, baik pada hati nuraninya, pada masyarakat dan Tuhan sebagai pencipta. ${ }^{3}$

\section{Aksiologi dalam Filsafat Ilmu}

Istilah aksiologi dalam bahasa Inggris adalah axiology. Berasal dari kata Yunani axios (layak, pantas), dan logos (ilmu, studi mengenai). Aksiologi memuat pikiran tentang masalah nilai-nilai termasuk nilai-nilai tinggi dari Tuhan. Misalnya nilai moral, nilai agama, nilai keindahan (estetika). Aksiologi daam filsafat Ilmu ini juga mengandung pengertian lebih luas daripada etika atau higher values of life (nilai-nilai kehidupan yang bertaraf tinggi). 4

Berbicara mengenai nilai, dapat kita jumpai dalam kehidupan seperti kata-kata adil dan tidak adil, jujur dan curang. Bukanlah itu semua mengandung penilaian karena manusia yang dengan perbuatannya berhasrat mencapai atau merealisasikan nilai. Teori nilai kaitannya dengan aksiologi, dapat kita bagi menjadi dua yaitu nilai etika dan nilai estetika.

Etika merupakan bagian dari aksiologi. Menurut Sadulloh (2009), istilah etika berasal dari kata "ethos" (Yunani) yang berarti adat kebiasaan.. Etika merupakan cabang aksiologi yang pada pokoknya membicarakan masalah predikat-predikat nilai "betul" (right), "salah"(wrong) dalam arti "susila" (moral) dan "tidak susila" (immoral). Etika dan moral sama artinya, tetapi dalam penilaian sehari-hari ada sedikit perbedaan. Moral dan atau moralitas dipakai untuk perbuatan yang sedang dinilai. Adapun etika dipakai untuk pengkajian sistem nilai yang ada. ${ }^{5}$

Sebagai cabang filsafat, etika sangat menekankan pendekatan yang kritis dalam melihat nilai (takaran, harga, angka kepandaian, kadar/mutu, sifat-sifat yang penting/berguna) dan moral tersebut serta permasalahan-

${ }^{3}$ Ibid, hlm. 239.

4 A. Susanto, (2011), Filsafat Ilmu, PT Bumi Aksara, Jakarta, hlm.116

${ }^{5}$ Surajiyo (2009). Filsafat Ilmu dan Perkembangannya di Indonesia. Bumi Aksara, Jakarta, hlm.147 
permasalahan yang timbul dalam kaitan dengan nilai dan moral itu. ${ }^{6}$ Etika oleh filsafat Yunani besar Aristoteles (384-322 SM) sudah dipakai untuk menunjuk filsafat moral. Secara etimologi berarti adat, kebiasaan. Pengertian etika mengandung makna meliputi:

a. Nilai-nilai dan norma-norma moral yang menjadi pegangan bagi seseorang atau suatu kelompok dalam mengatur tingkah lakunya.

b. Kumpulan asas atau nilai moral (kode etik)

c. Ilmu tentang yang baik atau buruk.

Istilah Estetika baru muncul pada tahun 1750 oleh seorang filsuf minor yang bernama A.G. Baumgarten (1714-1762). Istilah itu berasal dari bahasa Yunani kuno, aistheton, yang berarti kemampuan melihat lewat penginderaan. Baumgarten menamakan seni itu sebagai pengetahuan sensoris, yang dibedakan dengan logika yang dinamakannya pengetahuan intelektual. ${ }^{7}$

Estetika sering diartikan sebagai persepsi indra (sense of perception). Alexander Baumgarten (1714-1762), seorang filsuf Jerman adalah yang pertama memperkenalkan kata 'aisthetika', sebagai penerus pendapat Cottfried Leibniz (1646-1716). Baumgarten memilih estetika karena ia berharap dapat memberikan tekanan pada pengalaman seni sebagai suatu sarana untuk mengetahui (the perfection of sentient knowledge). Taste adalah hasil dari pendidikan dan kesadaran nilai-nilai budaya elit, sehingga rasa bisa dipelajari. Rasa bervariasi menurut kelas, latar belakang budaya, dan pendidikan. 8

\section{Membangun Karakter Guru berbasis Aksiologi}

Guru berkarakter menjadi pusat perhatian dari para ahli pendidikan, mengingat guru yang berkarakter ini sangat menentukan keberhasilan pendidikan. Dalam hubungan ini, Imam al-Ghazali misalnya mengatakan bahwa guru yang berkarakter adalah guru yang menerapkan pola hidup uhud (sederhana), ikhlas dalam melaksanakan tugasnya: menyayangi dan

\footnotetext{
${ }^{6}$ Ihsan Fuad (2010), Filsafat Ilmu. Rineka Cipta, Jakarta, hlm.271

${ }^{7}$ Daulat Saragi (2012), Estetika, Rineka Cipta, Jakarta, hlm.1

${ }^{8}$ http://www.scribd.com/doc/12854208/FILSAFAT-INDONESIA-DAN-PROFIL03Januari, 2011.diakses tanggal 02 April 2018. Pukul 22.00
} 
melindungi peserta didik, bersikap pemaaf atas kesalahan peserta didik dan orang lain, bersikap adil dalam memperlakukan anak didik, senantiasa menambah ilmunya. Berpandangan jauh kedepan dan mengarahkan peserta didik dalam melanjutkan studinya. ${ }^{9}$ Untuk lebih jauh dalam memahami bagaimana membangun karakter guru berbasis aksiologi, maka akan dilihat dari etika dan estetika yang merupakan bagian nilai-nilai dari aksiologi. Hal ini dapat kita lihat dari empat kompetensi yang harus dimiliki oleh guru.

\section{Kompetensi Guru}

Kompetensi berasal dari bahasa Inggris yaitu "competence" yang berarti kecakapan, kemampuan. Menurut Kamus Besar Bahasa Indonesia, kompetensi adalah kewenangan (kekuasaan) untuk menentukan dan memutuskan sesuatu. Dengan demikian tidaklah berbeda dengan pengertian kompetensi yang dikemukakan oleh W. Robert Houston seperti dikutip oleh Drs. Abd. Kadir Munsyi, Dip.Ad.Ed. yang mengatakan bahwa "competence" ordinarily is defined as "adequacy for a task" or as "possession of require knowledge skill and abilities". ${ }^{10} \mathrm{Di}$ sini dapat diartikan bahwa kompetensi sebagai salah satu tugas yang memadai atau pemilikan pengetahuan, keterampilan dan kemampuan yang dituntut oleh jabatan seseorang.

Berdasarkan Undang-undang Nomor 20 Tahun 2003 Tentang Pendidikan Masional, Undang-undang Guru dan Dosen No. 14 Tahun 2005 Pasal 2, guru diaktakan sebagai tenaga profesional yang mengandung arti bahwa pekerjaan guru hanya dapat dilakukan oleh seorang yang memiliki kualifikasi akademik, kompetensi, dan sertifikasi pendidik sesuai dengan persyaratan untuk setiap jenis dan jenjang pendidikan tertentu. Peraturan Pemerintah Nomor 19 Tahun 2005 tentang Standar Nasional Pendidikan menyebutkan bahwa guru adalah pendidik profesional. Seorang guru profesional harus memiliki kualifikasi akademik minimum sarjana (S1) atau Diploma empat (D-IV), menguasai kompetensi

\footnotetext{
${ }^{9}$ Abuddin Nata, Op Cit, hlm.240

${ }^{10}$ Syaiful Bahri Djamarah, Prestasi Belajar dan Kompetensi Guru, (Surabaya : Usaha Nasional, 1994), 33
} 
(pedagogik, kepribadian, sosial dan profesional), memiliki sertifikat pendidik, sehat jasmani dan rohani, serta memiliki kemampuan untuk mewujudkan tujuan pendidikan nasional. ${ }^{11}$

Untuk mengetahui lebih jauh karakter guru dilihat dari aspek aksiologi maka dapat kita lihat nilai etika yang meliputi kompetensi kepribadian dan kompetensi sosial. Sedang yang etika terdapat pada kompetensi pedagogi dan kompetensi profesional.

Aksiologi dalam fisafat ilmu berarti menyajikan hubungan antara etika dan ilmu, dimana etika sangat terkait hubungannya (inhaerent) dengan ilmu. Persoalan aksiologi adalah seputar bebas nilai atau tidaknya ilmu. Aksiologi juga merupakan studi tentang prinsip-prinsip dan konsep yang mendasari penilaian terhadap prilaku manusia. Nilai-nilai yang harus guru dikenalkan pada peserta didik untuk diadopsi yaitu kompetensi kepribadian adalah salah satu kompetensi yang mutlak harus dimiliki oleh guru, kepala sekolah, pengawas pendidikan.

1. Kompotensi Sosial

Fungsi kompetensi sosial guru secara umum yaitu motivator bagi siswa sebagai orang yang mengajarakan tentang makna pengabdian diri sebagai orang yang mengajarkan arti keikhlasan yang sebenarnya. Guru dapat bersikap inklusif, bertindak objektif, serta tidak diskriminatif karena pertimbangan jenis kelamin, agama, ras, kondisi fisik, latar belakang keluarga, dan status sosial ekonomi. Berkomunikasi secara efektif, empatik, dan santun dengan sesama pendidik, tenaga kependidikan, orang tua, dan masyarakat.

2. Kompotensi Kepribadian

Pada kompetensi kepribadian, guru dituntut untuk: (1) bertindak sesuai dengan norma agama, hukum, sosial, dan kebudayaan nasional pendidikan. Dalam hal ini seorang guru harus: menghargai peserta didik tanpa membedakan keyakinan yang dianut, suku, adat-istiadat, daerah asal dan gender, dan bersikap sesuai dengan norma agama yang dianut, hukum dan norma sosial yang belaku dalam masyarakat, serta kebudayaan nasional Indonesia yang beragam. (2) Menampilkan diri

${ }^{11}$ Jamil Suprihatiningrum (2013), Guru Profesional ;Pedoman kinerja, Kualifikasi \& Kompetensi Guru, Ar-Ruzz Media, Yogyakarta, hlm.106. 
sebagai pribadi yang jujur, berakhlak mulia, dan teladan bagi peserta didik dan masyarakat. Guru diharapkan: berperilaku jujur, tegas dan manusiawi, berperilaku yang mencerminkan ketakwaan dan akhlak mulia, dan berperilaku yang dapat diteladani oleh peserta didik dan anggota masyarakat di sekitarnya, menampilkan diri sebagai pribadi yang mantap, stabil, dewasa, arif, dan berwibawa. (3) Menunjukkan etos kerja, tanggung jawab yang tinggi, rasa bangga menjadi guru dan rasa percaya diri, meliputi: menunjukkan etos kerjadan tanggung jawab yang tinggi, Bangga menjadi guru dan percaya diri sendiri, dan bekerja mandiri secara profesional. (4) Menjunjung tinggi kode etik profesi guru, meliputi: memahami kode etik profesi guru, menerapkan kode etik profesi guru, dan berperilaku sesuai dengan kode etik guru.

Kompetensi kepribadian guru merupakan kemampuan personal yang mencerminkan kepribadian yang mantap, stabil, dewasa, arif dan berwibawa, menjadi teladan bagi siswa, dan berakhlak mulia. ${ }^{12}$ Kepribadian berkarakter juga teraktualisasikan dalam kode etik yang harus dimilki guru:

a. Dilihat dari kepentingan peserta didik

\begin{tabular}{|l|l|}
\hline \multicolumn{1}{|c|}{ Kode Etik } & \multicolumn{2}{|c|}{ Kepentingannya } \\
\hline $\begin{array}{l}\text { 1. Guru berkarakter } \\
\text { membimbing peserta }\end{array}$ & Guru dalam membimbing peserta \\
manusia Indonesia & didik perlu bersifat humanis- \\
seutuhnya yang berjiwa & demokratik untuk menciptakan \\
Pancasila & konformitas internalisasi bagi \\
& peserta didiknya. \\
& $\begin{array}{c}\text { Guru perlu mendorong } \\
\text { berkembangnya kemampuan yang }\end{array}$ \\
& ada pada diri peserta didik agar \\
& peserta didik dapat mengembangkan \\
& kemandirianya. Pengembangan \\
& kebebasan disertai dengan \\
& pertimbangan rasional perasaan, \\
& nilai dan sikap, ketrampilan dan \\
& pengalaman diri peserta didik. \\
\hline
\end{tabular}

${ }^{12}$ Ibid, hlm.106. 


\begin{tabular}{|c|c|}
\hline Kode Etik & Kepentingannya \\
\hline $\begin{array}{l}\text { 2. Guru berusaha } \\
\text { memperoleh informasi } \\
\text { tentang peserta didik } \\
\text { sebagi bahan melakukan } \\
\text { bimbingan dan pembinaan }\end{array}$ & $\begin{array}{l}\text { - Guru perlu menghadapi anak } \\
\text { didiknya secara tepat sesuai dengan } \\
\text { sifat-sifat khas yang ditampilkan } \\
\text { anak didiknya itu. } \\
\text { - Guru perlu menghadapi anak dengan } \\
\text { benar dalam membentuk tingkah } \\
\text { laku yang benar. } \\
\text { - Guru harus terhindar dari } \\
\text { pemahaman yang salah tentang } \\
\text { anak, khususnya mengenai } \\
\text { keragaman proses perkembangan } \\
\text { anak yang mempengaruhi } \\
\text { keragaman kemampuannya dalam } \\
\text { belajar. }\end{array}$ \\
\hline $\begin{array}{l}\text { 3. Guru menciptakan suasana } \\
\text { sekolah sebaik-baiknya } \\
\text { yang menunjang } \\
\text { berhasilnya PBM }\end{array}$ & $\begin{array}{l}\text { - Guru seharusnya memahami } \\
\text { perkembangan tingkah laku peserta } \\
\text { didiknya. Apabila guru memahami } \\
\text { tingkah laku peserta didik dan } \\
\text { perkembangan tingkah laku itu, } \\
\text { maka strategi, metode, media } \\
\text { pembelajaran dapat dipergunakan } \\
\text { secara lebih efektif. } \\
\text { - Tugas yang penting bagi guru dalam } \\
\text { melakukan pendekatan kepada } \\
\text { peserta didik adalah menjadikan } \\
\text { peserta didik tan mampu } \\
\text { mengembangkan keyakinan dan } \\
\text { penghargaan terhadap dirinya } \\
\text { sendiri, serta membangkitkan } \\
\text { kecintaan terhadap belajar secara } \\
\text { berangsur-angsur dalam diri peserta } \\
\text { didik. } \\
\text { Sesuai dengan pendapat Prayitno, } \\
\text { bahwa pembelajaran harus sesuai } \\
\text { konsep HMM (Harkat dan Martabat } \\
\text { Manusia). Antara guru dan peserta } \\
\text { didik terjalin hubungan yang } \\
\text { menimbulkan situasi pendidikan }\end{array}$ \\
\hline
\end{tabular}




\begin{tabular}{|c|c|}
\hline Kode Etik & Kepentingannya \\
\hline & $\begin{array}{l}\text { yang dilandasi dua pilar kewibawaan } \\
\text { dan kewiyataan. Pengaruh guru } \\
\text { terhadap peserta didik didasarkan } \\
\text { pada konformitas internalisasi. }\end{array}$ \\
\hline $\begin{array}{l}\text { 4. Guru memiliki dan } \\
\text { melaksanakan kejujuran } \\
\text { professional }\end{array}$ & $\begin{array}{l}\text { - Kejujuran adalah salah satu } \\
\text { keteladanan yang harus dijaga guru } \\
\text { selain prilaku lain seperti mematuhi } \\
\text { peraturan dan moral, berdisiplin, } \\
\text { bersusila dan beragama. } \\
\text { - Guru harus menjaga keteladanan } \\
\text { agar dapat diterima dan bahkan } \\
\text { ditiru oleh peserta didik. }\end{array}$ \\
\hline $\begin{array}{l}\text { 5. Menjaga hubungan baik } \\
\text { dengan orangtua, murid dan } \\
\text { masyarakat sekitar untuk } \\
\text { membina peran serta dan } \\
\text { tanggung jawab bersama } \\
\text { terhadap pendidikan }\end{array}$ & $\begin{array}{l}\text { - Guru harus bekerjasama dengan } \\
\text { orangtua dan juga lingkungan } \\
\text { masyarakat dalam pendidikan } \\
\text { Tanggung jawab pembinaan } \\
\text { terhadap peserta didik ada pada } \\
\text { sekolah, keluarga, dan masyarakat. } \\
\text { - Hal yang menyangkut kepentingan } \\
\text { si anak seyogyanya guru (sekolah) } \\
\text { mengajak orangtua dan bahkan } \\
\text { lingkungan masyarakat untuk } \\
\text { bermusyawarah. }\end{array}$ \\
\hline
\end{tabular}

b. Dilihat dari kepentingan antar pendidik

\begin{tabular}{|l|lr|}
\hline \multicolumn{1}{|c|}{ Kode Etik } & \multicolumn{2}{|c|}{ Kepentingannya } \\
\hline 6. Seorang guru harus saling & Etos kerja harus dijaga dengan \\
menghormati dan & menciptakan lingkungan kerja \\
menghargai sesama rekan & yang sehat dinamis, serta \\
seprofesi & menjaga hubungan baik dengan \\
& saling menghormati dan \\
& menghargai dan mau \\
& bekerjasama/ saling menolong \\
& antar sesame guru. & \\
\hline 7. Guru secara pribadi dan & Seharusnya guru tetap berusaha \\
bersama-sama & memacu diri untuk selalu \\
mengembangkan dan & mengembangkan & dan \\
\hline
\end{tabular}




\begin{tabular}{|c|c|}
\hline Kode Etik & Kepentingannya \\
\hline $\begin{array}{l}\text { meningkatkan mutu dan } \\
\text { martabat profesinya }\end{array}$ & $\begin{array}{l}\text { meningkatkan mutu pendidikan } \\
\text { dengan usaha pengembangan diri } \\
\text { yang optimal melalui pelatihan, } \\
\text { penataran, atau seminar. Jika } \\
\text { mutu guru baik, maka martabat } \\
\text { profesi guru juga akan meningkat. } \\
\text { - Guru juga seharusnya merubah } \\
\text { paradigma lama dengan } \\
\text { paradigma baru yang sesuai } \\
\text { dengan tuntutan kurikulum serta } \\
\text { senantiasa terus melakukan upaya } \\
\text { perbaikan dalam meningkatkan } \\
\text { mutu pendidikan } \\
\text { - Guru tidak melakukan perbuatan } \\
\text { yang bertentangan peraturan } \\
\text { Negara dan norma yang berlaku } \\
\text { yang dapat menjatuhkan harkat } \\
\text { dan martabat guru. }\end{array}$ \\
\hline $\begin{array}{l}\text { 8. Guru memelihara hubungan } \\
\text { seprofesi, semangat } \\
\text { kekeluargaan dan } \\
\text { kesetiakawanan sosial }\end{array}$ & $\begin{array}{l}\text { - Perlu ada hubungan yang } \\
\text { harmonis antar sesama profesi } \\
\text { guru. Tidak saling merendahkan } \\
\text { guru lain. Justru sebaliknya harus } \\
\text { saling menjaga martabat profesi } \\
\text { guru. Segala persoalan } \\
\text { diselesaikan dengan musyawarah } \\
\text { dan semangat kekeluargaan. } \\
\text { Terhadap sesama guru harus mau } \\
\text { saling bekerjasama dan memiliki } \\
\text { kesetiakawanan sosial (saling } \\
\text { menolong). }\end{array}$ \\
\hline $\begin{array}{l}\text { 9. Guru bersama-sama } \\
\text { memelihara dan } \\
\text { meningkatkan mutu } \\
\text { organisasi PGRI sebagai } \\
\text { sarana perjuangan dan } \\
\text { pengabdiannya }\end{array}$ & $\begin{array}{l}\text { - Sebagai anggota PGRI, guru } \\
\text { seharusnya aktif terlibat dalam } \\
\text { kegiatan organisasi. Berusaha } \\
\text { meningkatkan perjuangan dan } \\
\text { pengabdiannya terhadap dunia } \\
\text { pendidikan bersama-sama dengan } \\
\text { komponen bangsa lainnya. }\end{array}$ \\
\hline
\end{tabular}




\begin{tabular}{|c|c|}
\hline Kode Etik & Kepentingannya \\
\hline & $\begin{array}{l}\text { - Menjaga martabat PGRI sebagai } \\
\text { organisasi guru. }\end{array}$ \\
\hline $\begin{array}{l}\text { 10. Gurubersama-sama melaksa- } \\
\text { nakan segala kebijakan } \\
\text { pemerintah dalam bidang } \\
\text { pendidikan. }\end{array}$ & $\begin{array}{l}\text { - Seharusnya guru secara bersama- } \\
\text { sama membuat perangkat } \\
\text { pembelajaran (program tahunan, } \\
\text { program semester, silabus, RPP, } \\
\text { dan sistem penilaian) sesuai } \\
\text { kurikulum yang berlaku. } \\
\text { Perangkat disiapkan terencana } \\
\text { dan terjadwal. } \\
\text { - Guru/sekolah dilarang membuat } \\
\text { kebijakan yang bertentangan } \\
\text { dengan pemerintah di bidang } \\
\text { pendidikan. }\end{array}$ \\
\hline
\end{tabular}

Fungsi adanya kode etik adalah untuk menjaga kredibilitas dan nama baik guru dalam status pendidik. Secara subtansial untuk menambah kewibawaan dan memelihara image, citra profesi guru tetap baik. Kode etik guru juga mengatur tentang apa yang boleh dilakukan dan apa yang tidak boleh dilakukan dalam menjalankan tugas profesionalnya. ${ }^{13}$

3. Kompotensi Pedagogik

Kompetensi pedagogik mencakup pemahaman terhadap siswa, perencanaan dan pelaksanaan pembelajaran, evaluasi hasil belajar, dan pengembangan siswa untuk mengaktualisasikan berbagai potensi yang dimilikinya. ${ }^{14}$ Guru mampu memahami karakteristik peserta didik usia sekolah dasar yang berkaitan dengan aspek fisik, intelektual, sosialemosional, moral, spiritual, dan latar belakang sosial-budaya.

4. Kompetensi Profesional

Guru sebagai suatu jabatan profesional berarti orang yang bekerja pada bidang pendidikan dan pengajaran yang ikut bertanggung jawab dalam

${ }^{13}$ Mujtahid (2011), Pengembangan Profesi Guru, UIN Maliki Press, Malang. hlm. 42.

${ }^{14}$ Jamil Suprihatiningrum, Op Cit, hlm.101. 
membantu anak didik mencapai kedewasaannya masing-masing. ${ }^{15}$ Guru menguasai standar kompetensi dan kompetensi dasar mata pelajaran/bidang pengembangan yang dimampu. Oleh karena itu seorang guru yang profesional seharusnya memiliki kompetensi atau kemampuan yang baik dalam mengemban tanggung jawabnya itu. Kompetensi profesional, mencakup kemampuan dalam hal:

a. Mengerti dan dapat menerapkan landasan pendidikan baik filosofis, psikologis, dan sebagainya.

b. Mengerti dan dapat menerapkan teori belajar sesuai dengan tingkat perkembangan dan perilaku anak.

c. Mampu menangani mata pelajaran yang ditugaskan kepadanya.

d. Mengerti dan dapat menerapkan metode mengajar yang sesuai.

e. Dapat menggunakan berbagai alat pelajaran dan fasilitas belajar lain.

f. Dapat mengorganisasi dan melaksanakan program pengajaran.

g. Dapat mengevaluasi.

h. Dapat menumbuhkan pribadi anak. ${ }^{16}$

Seorang guru yang memenuhi persyaratan kemampuan profesional baik pendidik maupun pengajar atau pelatih, untuk menjamin proses belajar mengajar dan hasil belajar yang bermutu. Maka guru juga harus memiliki nilai-nilai estetika. ${ }^{17}$ Guru dalam menjalankan tugasnya harus menguasai pengetahuan, keterampilan dan kemampuan yang dituntut oleh jabatan seseorang. Keterampilan mengajar merupakan kompetensi profesional yang cukup kompleks, sebagai integrasi dari berbagai potensi guru secara utuh dan menyeluruh. Turney, sebagaimana dikutip Mulyasa, menggungkapkan bahwa delapan keterampilan mengajar sangat berperan dan menentukan kualitas pembelajaran. ${ }^{18}$

${ }^{15}$ Hadari Nawawi, Organisasi Sekolah dan Pengelolaan Kelas, (Jakarta: Tema Baru, 1999), 123

${ }^{16}$ Drs. Muhammad Ali (1997), Pengembangan Kurikulum di Sekolah, Sinar Baru, Bandung, hlm 37

${ }^{17}$ Mujtahidin (2011), Pengembangan Profesi Guru, UIN Maliki Press, Malang, $\operatorname{hlm} 5$.

${ }^{18}$ Muhammad Fathurrohman \& Sulistyorini. (2012), Pengembangan Profesi Guru, Teras, Yogyaarta, hlm 168. 
a. Keterampilan Membuka dan Menutup Pelajaran Yang dimaksud dengan membuka pelajaran (set induction) ialah usaha atau kegiatan yang dilakukan oleh guru dalam proses KBM untuk menciptakan prokondisi bagi siswa agar mental maupun perhatian terpusat pada apa yang akan dipelajari, dan usaha tersebut diharapkan akan memberikan efek positif terhadap kegiatan belajar. Menutup pelajaran (closure) ialah kegiatan yang dilakukan oleh guru untuk mengakhiri proses KBM. Penutup harus dipertimbangkan dengan sebaik mungkin agar sesuai, guru hendanya memberikan ringkasan dari pelajaran yang sudah disampaikan dan menyampaikan Rencana Pelajaran Berikutnya. ${ }^{19}$

b. Keterampilan Menjelaskan

Kegiatan "menjelaskan" dalam proses KBM bertujuan untuk membantu siswa memahami berbagai konsep, hukum, prosedur secara obyektif; membimbing siswa memahami pertanyaan; meningkatkan keterlibatan siswa; memberi kesempatan pada siswa untuk menghayati proses penalaran serta memperoleh feedback tentang pemahaman siswa. Apabila seorang guru menguasai "keterampilan menjelaskan" maka guru akan lebih mudah mengelola waktu dalam menyajikan materi, sehingga menjadi lebih efektif mengelola waktu. ${ }^{20}$

c. Keterampilan Bertanya

Pertanyaan yang baik akan menuntun pada jawaban yang sesungguhnya. Sebaliknya, pertanyaan yang buruk akan menjauhkan kita dari jawaban yang memuaskan. Hal ini senada dengan istilah question is knowledge. ${ }^{21}$ Ada enam tingkatan pertanyaan berdasarkan taksonomi Bloom, antara lain: pertanyaan pengetahuan (knowledge), pemahaman (comprehensif), penerapan/aplikasi (application), analisis, sistesis, dan evaluasi ${ }^{22}$

\footnotetext{
${ }^{19}$ Sulistiyorini (2009), Managemen Pendidikan Islam; Konsep, Strategi, dan Aplikasi. Teras., Yogyakarta, hlm. 94.

${ }^{20}$ Ibid, hlm. 96.

${ }^{21}$ Barnawi \& Mohammad Arifin (2012), Etika dan Profesi Kependidikan, Ar-Ruz Media,Yogyakarta, hlm.202

${ }^{22}$ Muhammad Fathurrohman \& Sulistyorini, Op Cit, hlm. 182.
} 
d. Keterampilan Memberi Penguatan

Penguatan (reinforcement) adalah segala bentuk respons, baik bersifat verbal maupun non verbal, yang merupakan bagian dari modifikasi tingkah laku guru terhadap tingkah laku siswa, bertujuan memberikan informasi atau umpan balik (feed back). ${ }^{23}$ Teknik pemberian penguatan dalam KBM yang bersifat verbal dapat dinyatakan melalui pujian, penghargaan atau pun persetujuan,. Manfaat penguatan bagi siswa adalah untuk meningkatkan perhatian, membangkitkan dan memelihara perilaku, menumbuhkan rasa percaya diri.

e. Keterampilan Menggunakan Variasi

Variasi adalah sesuatu yang lain dari biasanya, dan diperlukan agar suasana tidak monoton. Variasi yang bisa dilakukan seorang guru antara lain dengan variasi suara, mimik dan gerak, kesenyapan atau diam sejenak, perubahan posisi, pemusatan perhatian, dan kontak pandang. ${ }^{24}$ Beberapa "variasi" yang dapat dilakukan guru selama proses KBM di antaranya adalah: penggunaan variasi suara (teacher voice), pemusatan perhatian siswa (focusing), kesenyapan/kebisuan guru (teacher silence), kontak pandang dan gerak (eye contact and movement), gesture/gerak tubuh, ekspresi wajah guru, pergantian posisi guru dalam kelas dan gerak guru (teachers movement), variasi penggunaan media dan alat pengajaran. ${ }^{25}$

f. Keterampilan Mengelola Kelas

Dengan pengelolaan kelas yang baik diharapkan dapat tercipta kondisi kelas kelompok belajar yang proporsional terdiri dari lingkungan kelas yang baik yang memungkinkan siswa berbuat sesuai dengan kemampuan yang dimiliki, serta tersedia kesempatan yang memungkinkan untuk sedikit demi sedikit mengurangi ketergantungan terhadap guru, sehingga siswa mampu melakukan

\footnotetext{
${ }^{23}$ Ibid., hlm. 183.

${ }^{24}$ Barnawi \& Mohammad Arifin, Op Cit., hlm. 216.

${ }^{25}$ Muhammad Fathurrohman \& Sulistyorini, Op Cit, hlm. 188.
} 
self activity dan self control secara bertahap, tetapi pasti menuju taraf yang lebih dewasa. ${ }^{26}$

g. Keterampilan mengajar kelompok kecil dan perseorangan

Pengelompokan anak didik dalam proses interaksi edukatif merupakan pemebentukan organisasi sosial dalam pengajaran. Menurut Djamarah, ada tiga cara pengelompokkan yang dapat dilakukan, yaitu: atas dasar tugas-tugas khusus, atas dasar dinamika proses kelompok diantara anak didik, dan atas dasar pengalaman pembentukan kelompok yang telah dilakukan oleh guru dengan anak didik sebagai kelompok kerja. ${ }^{27}$

h. Keterampilan Membimbing Diskusi Kelompok Kecil

Diskusi kelompok kecil menurut Mulyasa, adalah suatu proses yang teratur dan melibatkan sekelompok orang dalam interaksi tatap muka untuk mengambil kesimpulan dan pemecahan masalah (problem solving). ${ }^{28}$

Dari delapan ketrampilan di atas, yang paling penting bagi seorang guru adalah bagaimana guru menerapkan keterampilan tersebut sehingga proses pembelajaran dapat berjalan baik. Sehingga siswa didiknya mampu memahami berbagai konsep yang disampaikan untuk kemudian mampu mengaplikasikannya dalam kehidupan sehari-hari. Proses pembelajaran yang dilakukan tidak semata-mata merupakan kegiatan transfer of knowledge namun juga transfer of moral value, maka setiap guru wajib menanamkan moral dalam setiap event tatap muka dengan siswa selama proses KBM. . ${ }^{29}$

\section{Usaha-Usaha untuk Membangun Karakter Guru Berbasis Aksiologi}

Membangun karakter guru diperlukan usaha-usaha yang harus dilakukan adalah dengan pembinaan dan pengembangan profesi guru, LPTK mempunyai tugas sebagai berikut.

\footnotetext{
${ }^{26}$ Sulistiyorini, Op Cit, hlm. 94.

${ }^{27}$ Muhammad Fathurrohman \& Sulistyorini, Op Cit, hlm. 192

${ }^{28}$ Ibid, hlm. 195

${ }^{29}$ Mahmudi, (1999), Supervisi Pendidikan, Sinar Baru, Bandung, hlm. 293.
} 
a. Mempersiapkan tenaga kependidikan.

b. Membina calon tenaga kependidikan maupun guru yang bertugas di sekolah untuk meningkatkan kompetensi mereka sehingga mampu meningkatkan mutu pendidikan di sekolah yang dibinanya. ${ }^{30}$

Mengenai guru telah ditegaskan pula bahwa pendidikan dan pembinaan guru serta tenaga kependidikan lainnya perlu ditingkatkan, karena sistem pendidikan diselenggarakan secara terpadu untuk menghasilkan guru yang mandiri. Oleh karena itu perlu meningkatkan kualitas proses belajar mengajar dengan cara pembinaan tenaga guru.

a. Urgensi pembinaan profesi bagi guru

1) Membantu guru dalam memahami strategi belajar mengajar. Maksud strategi di sini lebih mengutamakan kepada penghayatan akan nilai-nilai moral pancasila.

2) Membantu guru dalam cara merumuskan tujuan pembelajaran. Dalam hal ini yang menjadi masalah adalah bagaimana cara merumuskan TIK dalam bentuk tingkah-laku yang konkrit.

3) Membantu guru dalam cara merumuskan pengalaman belajar (learning experience) seperti melalui penjelasan atau ceramah, permainan (role playing, drama, demonstrasi, simulasi, dan sebagainya).

4) Membantu guru dalam cara mengaktifkan belajar. Keaktifan belajar itu diperoleh melalui penginderaan dan pengamatan serta fungsifungsi jiwa yang lain, sehingga keaktifan belajar melalui fungsifungsi jiwa.

5) Membantu guru dalam mengelola kelas dan mendinamiskan kelas sebagai suatu proses kelompok. ${ }^{31}$

b. Cara pembinaan guru secara intensif

1) Melalui Pre Cervice

Usaha perbaikan dan peningkatan kualitas mengajar guru melalui pre cervice ini adalah dimaksudkan untuk mengadakan pelayanan

${ }^{30}$ Cece Wijaya, Kemampuan Guru dalam Proses Belajar Mengajar, Rosda Karya. Bandun, hlm, 12

${ }^{31}$ Piet A. Sahertian, Prinsip dan Teknik Supervisi Pendidikan, (Surabaya: Usaha Nasional, 1992), 23 
pendidikan guru kepada mereka yang belum menjadi guru. Dalam hal ini lembaga pendidikan guru (Lembaga Pendidikan Tenaga Kependidikan) bertugas mempersiapkan para lulusan untuk menjadi guru. Program ini diberikan kepada mereka yang dari fakultas non perguruan untuk memperoleh kewenangan mengajar di berbagai sekolah dengan akta mengajar. ${ }^{32}$

2) Melalui In Cervice

Usaha pembinaan profesi guru melalui in cervice ini ditujukan kepada mereka yang sudah menjadi guru yang dilaksanakan pelayanannya oleh tenaga kependidikannya. ${ }^{33}$

c. Faktor pendukung dan cara peningkatan kompetensi guru

Ada beberapa faktor pendukung untuk meningkatkan kompetensi guru di antaranya adalah:

1) Melalui penataran, seperti: penataran melalui radio (siaran radio pendidikan), penataran yang diselenggarakan oleh proyek Departemen Pendidikan dan Kebudayaan, dan penataran tertulis yang diselenggarakan oleh Pusat Pengembangan dan Penataran Guru Tertulis.

2) Melalui belajar sendiri.

3) Melalui media massa seperti TV, majalah, surat kabar, dan sebagainya.

4) Melalui organisasi profesi berupa: diskusi kelompok, ceramah ilmiah, karya wisata, dan buletin organisasi, dsb. ${ }^{34}$

\section{Penutup}

Guru yang berkarakter adalah guru yang memiliki akhlak mulia, budi pekerti, sopan santun, etika, agama, dan nilai-nilai kewarganegaraan. Aksiologi dalam filsafat Ilmu mengandung pengertian lebih luas daripada etika atau higher values of life (nilai-nilai kehidupan yang bertaraf tinggi) dan estetika.

${ }^{32}$ Ibid, 23

${ }^{33}$ Mahmudi, (1999), Supervisi Pendidikan, Sinar Baru, Bandung.

34 Suryono Subroto (1998), Dimensi-Dimensi Administrasi di Sekolah, Bina Aksara, Jakarta, hlm 142 
Guru harus terus melakukan pembinaan dan peningkatan kualitas agar menjadi guru yang berkarakter yang teraktualisasikan dalam guru yang profesional sehingga sistem pendidikan diselenggarakan secara terpadu untuk menghasilkan peserta didik menjadi manusia seutuhnya sebagaimana yang temaktub dalam tujuan pendidikan.

\section{DAFTAR PUSTAKA}

Ali, M. 1997. Pengembangan Kurikulum di Sekolah. Bandung: Sinar Baru.

Barnawi \& Arifin, M. 2012. Etika dan Profesi Kependidikan. Yogyakarta: ArRuz Media.

Djamarah, S. B. 1994. Prestasi Belajar dan Kompetensi Guru. Surabaya: Usaha Nasional.

Fathurrohman, Muhammad \& Sulistyorini. 2012. Pengembangan Profesi Guru. Yogyakarta: Teras.

Hadari, Nawawi. 1999. Organisasi Sekolah dan Pengelolaan Kelas. Jakarta: Tema Baru.

Ihsan, Fuad. 2010. Filsafat Ilmu. Jakarta: Rineka Cipta.

Jamil, Suprihatiningrum. 2013. Guru Profesional; Pedoman kinerja, Kualifikasi $\mathcal{E}$ Kompetensi Guru. Yogyakarta: Ar-Ruzz Media.

Mahmudi. 1999. Supervisi Pendidikan. Bandung: Sinar Baru.

Mujtahidin. 2011. Pengembangan Profesi Guru. Malang: UIN Maliki Press.

Nata, A. 2012. Kapita Selekta Pendidikan Islam. Jakarta: Raja Grafindo Persada. 
Sahertian, P. A. 2013. Prinsip dan Teknik Supervisi Pendidikan. Surabaya: Usaha Nasional.

Saragi, D. 2012. Estetika. Jakarta: Rineka Cipta.

Subroto, S. 1998. Dimensi-Dimensi Administrasi di Sekolah. Jakarta: Bina Aksara.

Sulistiyorini. 2009. Managemen Pendidikan Islam; Konsep, Strategi, dan Aplikasi. Yogyakarta: Teras.

Susanto, A. 2011. Filsafat Ilmu. Jakarta: Bumi Aksara.

Surajiyo. 2009. Filsafat Ilmu dan Perkembangannya di Indonesia. Jakarta: Bumi Aksara.

Suprihatiningrum, J. 2013. Guru Profesional ;Pedoman kinerja, Kualifikasi E Kompetensi Guru. Yogyakarta: Ar-Ruzz Media.

Wijaya, C. 1991. Kemampuan Guru dalam Proses Belajar Mengajar. Bandung: Rosda Karya.

http://www.scribd.com/doc/12854208/FILSAFAT-INDONESIA-DANPROFIL-03Januari, 2011.diakses tanggal 28 April 2018. Pukul 22.00 